The following document is a pre-print version of:

Ross P-S, Mercier-Langevin P (2014) The volcanic setting of VMS and SMS deposits: a review. Geoscience Canada, DOI 10.12789/geocanj.2014.41.045

\title{
The volcanic setting of VMS and SMS deposits: a review
}

\author{
Pierre-Simon Ross* \\ Institut national de la recherche scientifique, centre Eau Terre Environnement, 490 rue de la Couronne, Québec (Qc) \\ G1K 9A9, Canada, Ph. 418-654-3773, Email rossps@ete.inrs.ca \\ * Corresponding author
}

Patrick Mercier-Langevin

Geological Survey of Canada, 490 rue de la Couronne, Québec (QC), G1K 9A9, Canada pmercier@ nrcan.gc.ca

\begin{abstract}
SUMMARY
Volcanogenic massive sulfide (VMS) deposits and seafloor massive sulfide (SMS) deposits have a spatial and genetic connection with contemporaneous volcanism. The control exerted by the volcanic succession (e.g., rock type, architecture and facies) on the nature and style of the ore and alteration (e.g., subsea-floor replacement vs. exhalative, or discordant vs. conformable) is significant, making it imperative to understand the local volcanology in developing better genetic and exploration models.
\end{abstract}

Three deposit groupings that cover a good proportion of cases are discussed. First, many deposits are associated with complexes of submarine felsic domes, cryptodomes and/or blocky lavas, and their reworked equivalents. Lobe-hyaloclastite flows can also be associated with VMS deposits. Second, some SMS and VMS deposits are associated with thick piles of pumiceous felsic pyroclastic rocks, suggesting a caldera context. However, demonstrating a caldera in ancient successions can be difficult because silicic calderas tend to be large and exceed the limits of deposit-scale investigations. Furthermore, there is no consensus regarding what a large submarine caldera should look like, i.e. no accepted facies model showing the distribution of rock types. Without thick piles of pumiceous felsic pyroclastic deposits, arguing for a large submarine caldera is a challenge.

Finally, it is important to stress that several, and some significant, VMS deposits are associated with mafic volcanic footwalls, including the $\sim 300 \mathrm{Mt}$ Windy Craggy deposit in British Columbia, and/or with sedimentary hosts.

\section{RÉSUMÉ}

Les gisements de sulfures massifs volcanogènes (SMV) et leurs équivalents actuels au fonds des mers ont une connexion spatiale et génétique avec le volcanisme. La succession volcanique - composition, architecture, faciès - exerce un contrôle important sur la nature et le style de minéralisation et d'altération hydrothermale (p. ex. minéralisation mise en place par remplacement sous le fond marin vs. exhalative; altération discordante ou plus concordante). Il est donc impératif de connaître la volcanologie des roches encaissantes pour développer de meilleurs modèles génétiques et d'exploration. Trois groupes de gisements couvrant une bonne proportion des cas sont discutés ici.

Premièrement, plusieurs gisements sont associés à des dômes felsiques sous-marins, des cryptodômes et/ou des laves en blocs, ou leur équivalent resédimenté. Des coulées de type lobes-hyaloclastite peuvent aussi être associés à des gisements. Deuxièmement, certains gisements sont associés à d'épaisses séquences de roches pyroclastiques felsiques ponceuses, suggérant un contexte de caldeira. Néanmoins, la démonstration de l'association entre un gisement et une caldeira peut être difficile dans les successions anciennes car les caldeiras felsiques sont de grandes dimensions, excédant alors les limites des études à l'échelle du gîte. De plus, il n'existe pas de consensus sur un modèle de faciès pour une grande caldeira sous-marine. Mais sans la présence d'épais empilements de roches pyroclastiques felsiques ponceuses, il est difficile d'argumenter en faveur d'une caldeira sous-marine. Troisièmement, plusieurs gisements, dont certains importants, sont associés avec des roches volcaniques mafiques, par exemple le dépôt de Windy Craggy ( 300 Mt) en Colombie-Britannique, et/ou avec des roches sédimentaires. 


\section{INTRODUCTION}

About 300 sites with accumulations of seafloor massive sulphide (SMS) are known on the modern ocean floor (Shanks and Thurston 2012). Of these, 65\% are located on mid-ocean ridges, $22 \%$ are found in back-arc basins and $12 \%$ are on submarine arcs (Hannington et al. 2005). They may be mined for their base and precious metals one day. These deposits are the modern equivalent of the ancient volcanogenic massive sulphide (VMS) deposits on land. VMS deposits are "strata-bound accumulations of sulphide minerals that precipitated at or near the sea floor in spatial, temporal and genetic association with contemporaneous volcanism" (Franklin et al. 2005). They are thought to have been predominantly formed, or at least preferentially preserved, in arc and back-arc settings. VMS deposits represent major sources of $\mathrm{Ag}, \mathrm{Au}, \mathrm{Cu}$, $\mathrm{Pb}$ and $\mathrm{Zn}$ (Barrie and Hannington 1999; Allen and Weihed 2002); for example, they account for half of Canada's $\mathrm{Zn}$ production and nearly a third of its $\mathrm{Cu}$ (Galley et al. 2007), making them attractive targets for exploration. Historically, many VMS deposits have been found by geophysical and other direct methods of detection; such methods work best at shallow depths. The necessity to explore at greater depth in mature camps forces geologists not only to recognize direct evidence for mineralization, but also favourable host environments. Physical volcanology ${ }^{1}$ studies such as those reviewed here can help identify favourable host environments for VMS mineralization.

\section{Lithostratigraphic and volcanological VMS}

classifications. A number of VMS classification methods were proposed in the past, but currently the most common classification uses a "lithostratigraphic scheme based primarily on the principal volcanic and sedimentary lithological units that formed concurrently with the deposits in a given district" (Franklin et al. 2005). This scheme includes five types: (1) bimodalmafic, (2) mafic, (3) pelitic-mafic, (4) bimodal-felsic, (5) siliciclastic-felsic (Franklin et al. 2005). Galley et al. (2007) added a sixth group, "hybrid bimodal felsic", for deposits that combine epithermal and VMS characteristics and that are thought to have formed in a shallow water setting.

Building on the work of Morton and Franklin (1987), Gibson et al. (1999) separated VMS deposits hosted by volcanic rocks into two types: "flow dominated" and "volcaniclastic dominated". This field classification is

\footnotetext{
${ }^{1}$ According to Gibson et al. (1999), in the context of VMS exploration, physical volcanology is the study of "(1) the products and deposits formed by volcanic eruptions, (2) eruptive mechanisms, (3) processes of emplacement, and (4) landforms produced by eruptions".
}

based on the character of the footwall strata, up to $1 \mathrm{~km}$ below the deposit or more. According to Gibson et al. (1999), Doyle and Allen (2003) and Franklin et al. (2005), the character of the submarine volcanic rocks, whether coherent lava (massive or pillowed lava flows, lava dome cores) or fragmental (volcaniclastic rocks of all types ${ }^{2}$ ), influences:

(a) the size, morphology and growth mechanism of the VMS deposit, i.e. whether it is a mound-shaped sulphide lens formed mostly on the sea floor, with an underlying discordant stockwork, or a tabular sulphide body formed mostly by sub-sea floor replacement, with a more localized stringer zone or no stringer zone; (b) the size, shape and composition of the proximal footwall alteration, i.e. whether it is a discordant pipe of chlorite-sericite-quartz $\square$ carbonate or a broad diffuse zone of sericite, quartz, aluminous silicate and carbonate, with local chlorite; and

(c) the character of regional semi-conformable alteration zones.

\section{Importance of physical volcanology studies. The} control exerted by the volcanic succession (e.g., rock type, architecture and facies) on the nature and style of the ore and alteration (e.g., subsea-floor replacement vs. exhalative, or discordant vs. conformable) is significant, making it essential to understand the physical volcanology in developing better genetic and exploration models. Physical volcanology studies can help locate synvolcanic structures, which control the location of VMS deposits and can represent coincident effusive and hydrothermal centres (Gibson et al. 1999). In other words, VMS deposits are commonly associated with proximal volcanic settings (e.g., Gibson et al. 1993; Allen et al. 1996a; Allen and Weihed 2002). Field and drill core studies of lateral and vertical facies variations can help reconstruct the volcanic setting of VMS deposits and identify potentially fertile areas (e.g., McPhie et al. 1993; Gibson et al. 1999; Rogers et al. 2014).

Scope of this review. In this paper we review the volcanic settings of VMS and SMS deposits associated with: (1) felsic dome complexes and lavas; (2) pumiceous felsic pyroclastic rocks (submarine calderas); and (3) basaltic volcanic rocks and sills. The first category is probably the most common (Allen and Weihed 2002). However, the first two categories are

\footnotetext{
${ }^{2}$ In this paper, we follow the terminology of White and Houghton (2006) to describe fragmental volcanic rocks. In this scheme, there are four types of primary volcaniclastic rocks: pyroclastic ("sedimentation from pyroclastic plumes and currents"), autoclastic ("deposition of fragments from lava, formed via air cooling"), hyaloclastite ("deposition of fragments from lava, formed via water chilling") and peperite ("mingling of magma with wet sediment").
} 
not mutually exclusive, since felsic domes can occur in calderas, but it is interesting to contrast districts where calderas exist (type 2) with districts where calderas are absent, are being questioned, or have never been proposed (type 1). This contribution is intended as a short review to illustrate the subject, rather than a comprehensive one, therefore many examples and references had to be left out.

\section{VMS DEPOSITS ASSOCIATED WITH FELSIC DOME COMPLEXES AND LAVAS}

It has long been known that complexes of submarine felsic domes and/or blocky lavas, as well as cryptodomes, can be spatially associated with VMS deposits, especially of the bimodal-mafic, bimodalfelsic and siliciclastic-felsic types (e.g., Allen 1992; Cas 1992; Doyle and Allen 2003; Franklin et al. 2005). In addition lobe-hyaloclastite flows, which are longer lavas with lesser proportions of hyaloclastite (Gibson et al. 1999) can also be associated with VMS deposits. Examples from five districts are reviewed, ranging in age from modern to Archean.

\section{Manus Basin \\ The Canadian company Nautilus Minerals has identified 17 SMS prospects in the Manus (back-arc) basin off Papua New Guinea (Lipton 2012). Their "Solwara-1" prospect (a.k.a. Susu Knolls: Binns and Scott 1993) is a candidate for the first underwater mining operation of a SMS deposit, but in terms of physical volcanology, Solwara-4 - formerly called Pacmanus - is better known (Binns and Scott 1993; Scott and Binns 1995). The Ocean Drilling Program obtained several cores of the volcanic rocks and sulphide mineralization from Solwara-4 as part of leg 193; Paulick et al. (2004) show from these cores that the SMS deposits are directly underlain by a dacitic sequence, which they interpret as a series of 40-100 m thick lava flows and/or domes and associated breccias (Fig. 1). A reconstruction of the volcanic pile shows a number of juxtaposed and superimposed felsic lavas or domes with coherent cores and fragmental sides and tops, as is typical of felsic submarine lavas and domes (e.g. McPhie et al. 1993). Scott and Binns (1995) compared the Solwara-4 site with the Millenbach VMS deposit in the Noranda district (Abitibi greenstone belt), where the ore also sits on top of a complex of felsic domes (see below).}

\section{Hokuroku district}

Several Cu-Zn-Pb-Ag-Au VMS deposits of Miocene age ( 15-12 Ma; Tanimura et al. 1983; Allen and Weihed 2002; Yamada and Yoshida 2011), locally known as "Kuroko" deposits, have been exploited in the Green Tuff Belt of Japan, including a cluster of 12 deposits in the Hokuroku district of northern Honshu (e.g., Ohmoto 1996). The total past production of Hokuroku district deposits is estimated at $\sim 90 \mathrm{Mt}$ (Yamada, pers. commun. 2007). The Kuroko deposits developed in a submarine arc undergoing extension (Yamada and Yoshida 2011). Specifically, the Hokuroku district is found in the Kuroko Rift, which contains over $80 \%$ felsic rocks (Yamada and Yoshida 2011), and the VMS deposits are of the bimodal-felsic type (Franklin et al. 2005).

It has been suggested that a number of submarine calderas occur in the Hokuroku district (e.g., Ohmoto and Takahashi 1983; Ohmoto 1996; and references therein) and that felsic pyroclastic rocks are abundant in the district (e.g., Ohmoto and Takahashi 1983; Tanimura et al. 1983). However, Cas (1992) proposed that fragmental rocks around the Kuroko deposits are predominantly hyaloclastite, rather than pyroclastic rocks. He also stated that typical caldera-filling deposits (submarine ignimbrites) are absent in the Hokuroku district and that caldera-bounding faults have not been recognized. However, dacitic to rhyolitic domes and associated breccias are closely associated with the Kuroko ores (Horikoshi 1969; Cas 1992). For example, Kuroda (1983) shows a model for the Furutobe deposit where the ore is formed in volcaniclastic rocks near a dome. Yamada and Yoshida (2011) show a cross-section of the $\sim 30 \mathrm{Mt}$ (Tanimura et al. 1983) Matsumine deposit where the ore sits between two rhyolite domes (Fig. 2). It seems clear that the VMS deposits of the Hokuroku district are associated with lava domes, but not submarine calderas (Cas, 1992; Allen and Weihed 2002).

\section{Iberian pyrite belt}

About 90 VMS deposits occur in the Iberian pyrite belt of Spain and Portugal, of which seven or eight are larger than $100 \mathrm{Mt}$, making it one of the most important VMS regions of the world (Allen and Weihed 2002; Rosa et al. 2010). Mercier-Langevin et al. (2014) calculate that the Iberian pyrite belt contains $23 \%$ of the global VMS tonnage. The rocks hosting the VMS deposits are Devonian to Carboniferous in age; the succession is dominated by sedimentary rocks, especially mudstones, but mafic to felsic volcanic rocks are also present (Tornos 2006). Soriano and Marti (1999) concluded that volcanism in the eastern part of the Iberian pyrite belt was mostly non-explosive. Rosa et al. (2010) reviewed felsic volcanic centres in the belt and concluded that "these volcanoes are dominated by felsic lavas/domes that occur at several stratigraphic positions... however the pyroclastic units are also abundant".

Rosa et al. (2008) made a detailed study of the volcanic rocks near the $300 \mathrm{Mt}$ (Relvas et al. 2006) Neves Corvo 
deposit in Portugal and convincingly showed that the immediate footwall includes a coherent to fragmental rhyolite unit forming a series of domes or lavas (Fig. 3 ). The total thickness of rhyolite is typically $85-135 \mathrm{~m}$. The rhyolitic rocks are highly altered and have the same age as the ores (Rosa et al. 2008). Relvas et al. (2006) show photos of sulphides replacing rhyolitic rocks, probably of a fragmental nature. The domes or lavas were emplaced in a submarine epicontinental sedimentary basin (Rosa et al. 2008).

\section{Skellefte district}

The Skellefte district of northern Sweden is of Paleoproterozoic (1.9-1.87 Ga) age and contains about 85 VMS deposits and occurrences (Allen et al. 1996a), of which 31 have been put into production (MercierLangevin et al. 2013). In the 1980s, the felsic volcanic rocks in the district were thought of as pyroclastic and related to large calderas, but Allen et al. (1996a) note that "many volcanic rocks in the district, including many originally homogeneous intrusions and lavas, have streaky, patchy, pseudotuffaceous textures" due to diagenetic compaction and tectonic fabrics. Instead of being found in calderas, several VMS deposits are closely associated with a specific type of volcano called "subaqueous rhyolite cryptodome-tuff volcano" (Allen et al. 1996a). This type of volcano occupies 5\% or less of the Skellefte district but many VMS deposits occur in such rocks, or above them (Fig. 4). According to Allen et al. (1996a), "these rhyolite volcanoes are 2 to $10 \mathrm{~km}$ in diameter, 250 to $1200 \mathrm{~m}$ thick at the center, and are characterized by a small to moderate volume rhyolitic pyroclastic unit, intruded by rhyolite cryptodomes, sills, and dikes. Massive sulfide ores occur near the top of the proximal (near vent) facies association". The first magma batch was gas-rich and erupted explosively to form the pyroclastic unit (the "tuff cone" on Fig. 4), which is thickest in the vent area $(50-300 \mathrm{~m})$. The pyroclastic unit is thickly bedded, pumiceous, and probably accumulated in depressions on the seafloor. It was then intruded by gas-poor magma which formed "sills, dikes, cryptodomes, partly emergent cryptodomes, and possibly some lavas" (Allen et al. 1996a).

\section{Abitibi greenstone belt}

The Archean Abitibi greenstone belt of Quebec and Ontario contains a VMS tonnage of over $800 \mathrm{Mt}$ (Galley et al. 2007; Goutier et al. 2011; MercierLangevin et al. 2011). We focus on two VMS areas from the southern Abitibi belt: Kidd Creek (a large isolated deposit) and the Noranda district. A mention is also made of recent work in the Matagami district.

The Kidd Creek deposit in Ontario, is classified as bimodal-mafic (Galley et al. 2007) with $\sim 185$ Mt of ore grading $2.3 \% \mathrm{Cu}, 6.2 \% \mathrm{Zn}, 0.2 \% \mathrm{~Pb}, 74 \mathrm{~g} / \mathrm{t} \mathrm{Ag}$, and $0.01 \mathrm{~g} / \mathrm{t} \mathrm{Au}$ (Goutier and Bécu, unpublished compilation, 2013). The deep footwall consists of komatiitic rocks, whereas the immediate footwall is a 300 m-thick rhyolitic package (Bleeker 1999; Hannington et al. 1999). The lower part of the rhyolite sequence is mostly coherent and interpreted as domes and lavas, whereas the upper part is dominated by bedded volcaniclastic rocks inferred to fill a graben (Bleeker 1999). These volcaniclastic rocks are interpreted as mostly derived from felsic domes or lavas as well (Fig. 5). The ores formed mostly by subsea-floor replacement of these fragmental rocks (Bleeker 1999; Hannington et al. 1999).

In the central part of the Noranda district (Quebec), 17 small (typically $\sim 0.5-4.5 \mathrm{Mt}$ ) bimodal mafic $\mathrm{Cu}-\mathrm{Zn}$ deposits occur in a lava-dominated volcanic succession (Gibson and Watkinson 1990). The Rouyn-Noranda area has good outcrop and is a classic locality for submarine volcanology and VMS studies. Two types of rhyolitic volcanoes are known in the Noranda district, blocky lavas/domes and lobe-hyaloclastite flows (Gibson et al. 1999) and both can be associated with VMS mineralization. The Millenbach mine area is a good example of VMS mineralization associated with a blocky rhyolitic lava/dome. This dome/flow is described as a "1.8 km-long northeast-trending ridge that directly overlies its feeding fissure" (Gibson et al. 1999). The maximum thickness of rhyolite is $250 \mathrm{~m}$ and the slopes of the ridge range from 30 to $70 \square$. The interior of the ridge consists of coherent rhyolite whereas the top and sides consist of breccias (Fig. 6). The breccias are up to $30 \mathrm{~m}$ thick (Gibson et al. 1999). Ore occurred "along the top of the rhyolite ridge and directly above and along the feeding fissure" (Gibson and Galley 2007), forming a series of 15 VMS bodies up to $\sim 1 \mathrm{Mt}$ in size (Gibson et al. 1999). Knuckey et al. (1982) show a "QFP dome" isopach map supporting this interpretation.

In contrast, ore occurred immediately above lobehyaloclastite flows at the Ansil, Vauze, and Norbec deposits in the Noranda district (Gibson et al. 1999). Lobe-hyaloclastite flows comprise a lower proportion of fragmental rocks relative to blocky domes/flows. They form "broad, gentle-sloped (10 $\square-20 \square$ ) lava shields or plateaus that attained heights of up to 500 $\mathrm{m}$ ", are fed by fissures and can reach $5 \mathrm{~km}$ in radius (Gibson et al. 1999). Recent studies in the Matagami district, in the northern part of the Abitibi greenstone belt, suggest that lobe-hyaloclastite flows are also the dominant type of felsic lavas immediately below and above the Zn-rich VMS deposits of the district (Debreil 2014). 


\section{VMS DEPOSITS ASSOCIATED WITH PUMICEOUS FELSIC PYROCLASTIC ROCKS}

Some SMS and VMS deposits are associated with pumiceous felsic pyroclastic rocks that formed in a submarine caldera setting. Brothers volcano, in the Kermadec-Tonga arc, north of New Zealand, is an example of a submarine caldera that has SMS mineralization forming in it today (de Ronde et al. 2005). Several scientific cruises have visited this volcano and an active hydrothermal field has been mapped (Baker et al. 2012 and references therein). Ancient examples of VMS deposits in felsic submarine calderas are found in the Proterozoic Bergslagen district of Sweden (Allen et al. 1996b) and the Archean Sturgeon Lake district of Ontario (bimodal-felsic type; Hudak et al. 2003 and references therein).

\section{Submarine calderas \\ Because submarine calderas are not well known, we start by describing their continental equivalents. The largest continental calderas - which can reach tens of kilometres in diameter - are associated with catastrophic explosive eruptions of gas-rich felsic magmas (e.g., Cole et al. 2005 and references therein). The top of the magma chamber empties rapidly because of the catastrophic explosive eruption, and this leads to caldera collapse (Smith and Bailey 1968). The typical products of such eruptions are pumiceous pyroclastic flow deposits (ignimbrites). Within the caldera, these deposits can be up to kilometres in thickness, but outside the caldera they are much thinner (Lipman 1997). Very thick sequences of pumiceous, poorly sorted felsic pyroclastic rocks are thus compatible with a caldera setting, even if the original caldera geometry cannot be recognized in ancient rocks.}

Submarine calderas are less known, but the largest ones also seem to be associated with large explosive eruptions of felsic magma (e.g., Fiske et al. 2001; Yuasa and Kano 2003) and form by the same mechanism of roof collapse above a rapidly emptying magma chamber. The felsic calderas of the northern Isu-Bonin arc range in diameter from 2 to $10 \mathrm{~km}$, which is relatively small compared to continental calderas, and the explosive eruptions create large volumes of pumice (Yuasa and Kano 2003). These felsic submarine calderas occupy a large area of the inferred original volcanic edifice unlike mafic calderas where the collapse area represents only a small portion of the volcanic edifice (e.g. subaerial shield volcanoes in Hawaii). Mafic calderas form as a result of magma withdrawal (e.g., Walker 1993).

Stix et al. (2003, and references therein) proposed that submarine calderas should be excellent hosts for VMS deposits, especially near the caldera margin, because "caldera opening along outward-dipping faults promotes magma degassing, seawater influx, and hightemperature leaching, resulting in a metal-rich hydrothermal fluid" (Fig. 7). Furthermore, "the accumulation of significant thicknesses of pyroclastic deposits within the caldera is an important source of stratigraphic permeability, which can be exploited by mineralizing solutions" to form VMS deposits by subseafloor replacement (Stix et al. 2003). Two good examples, one modern from the Isu-Bonin arc, and one ancient from northern Maine, are now presented in some detail.

\section{Isu-Bonin arc}

The Myojin Knoll caldera in the Isu-Bonin arc south of Japan contains an actively forming SMS deposit that was discovered in the 1990s (Iizasa et al. 1999). The 6 x $7 \mathrm{~km}$ Myojin Knoll caldera occupies the centre of a $950 \mathrm{~m}$-high, 19 x $22 \mathrm{~km}$ diameter submarine felsic volcano (Fiske et al. 2001). A 2 km-diameter, $250 \mathrm{~m}$ high, post-caldera felsic dome occupies the centre of the caldera floor. The collapse volume is $\sim 18 \mathrm{~km} 3$ and the caldera is surrounded by a non-stratified to poorly stratified pumice layer, up to $200 \mathrm{~m}$ thick, which thins outward from the caldera margin (Fig. 8). Fiske et al. (2001) propose that the caldera formed as a result of a catastrophic felsic explosive eruption. Following caldera collapse, massive sulphides began accumulating in the eastern part of the caldera floor, along the inferred trace of the main caldera fault. The Sunrise deposit (Fig. 8) is $400 \mathrm{x} 400 \mathrm{~m}$ in map view, and is reportedly $30 \mathrm{~m}$ thick, generating an estimate of $9 \mathrm{Mt}$ of massive sulphides that are exceptionally rich in base and precious metals (Iizasa et al. 1999), although the deposit has not been drilled to confirm this thickness and tonnage.

\section{Bald Mountain}

The Ordovician Bald Mountain VMS deposit in northern Maine, a bimodal-felsic type, contains $30 \mathrm{Mt}$ of hypogene ore at average grades of $1.0 \% \mathrm{Cu}, 1.1 \%$ $\mathrm{Zn}, 0.4 \% \mathrm{As}, 0.5 \mathrm{~g} / \mathrm{t} \mathrm{Au}$, and $14 \mathrm{~g} / \mathrm{t} \mathrm{Ag} \mathrm{(Slack} \mathrm{et} \mathrm{al.}$ 2003). The metamorphic grade is sub-greenschist, cleavage is lacking, and primary textures are well preserved (Busby et al. 2003; Slack et al. 2003), making this area ideal to study the volcanic host rocks of a VMS deposit. The inferred setting for the volcanic and hydrothermal activity is a deep water $(>1.5 \mathrm{~km})$ graben in a primitive volcanic arc (Busby et al. 2003). The deep footwall consists of at least $2 \mathrm{~km}$ of submarine tholeiitic basalts and basaltic andesites (lavas) (Fig. 9a). The immediate footwall and hangingwall is a thick ignimbrite package that contains the VMS deposit. The $\sim 200 \mathrm{~m}$-thick footwall ignimbrite, a crystal-poor, non-welded, non-stratified, 
pumiceous felsic lapillistone, formed as a result of a major underwater explosive eruption that formed the Bald Mountain sub-basin (Busby et al. 2003), which is possibly a caldera (Fig. 9a). After this, the up to $215 \mathrm{~m}$ thick VMS deposit formed in the inferred vent of the crystal-poor ignimbrite (Busby et al. 2003); sulphides precipitated through a combination of chimney growth and subsea-floor replacement (Slack et al. 2003). Finally, the $\sim 350$-m thick crystal-rich hangingwall ignimbrite sequence (including andesitic lava intercalations) formed and covered the Bald Mountain deposit (Fig. 9b). This mostly explosive eruption was accompanied by the collapse of the Bull Hill sub-basin, another possible caldera (Busby et al. 2003).

VMS DEPOSITS ASSOCIATED WITH BASALTS Ophiolite-hosted VMS deposits in Cyprus and Oman are enclosed in basaltic volcanic rocks (Hannington et al. 1998). Another good example is the Jurassic TurnerAlbright VMS deposit in Oregon ( $3 \mathrm{Mt})$, where the bulk of the mineralization formed by replacement of basaltic hyaloclastite (Zierenberg et al. 1998). On the modern sea floor, SMS deposits such as TAG are actively forming in a mafic setting (Hannington et al. 1998).

In Canada, the Windy Craggy VMS deposit of northern British Columbia (pelitic-mafic type), is an excellent example of a very large VMS deposit $(\sim 300 \mathrm{Mt})$ within a succession of Triassic sedimentary and mafic volcanic to intrusive rocks (Fig. 10; Peter and Scott 1999). The host rocks consist of "interbedded pillow basalt and graphitic to calcareous siltstone and argillite" with local basaltic sills (Peter and Scott 1999).

\section{DISCUSSION AND CONCLUSIONS}

Three categories of SMS and VMS deposits are described in this review: (1) deposits associated with felsic dome complexes and lavas; (2) deposits associated with pumiceous felsic pyroclastic rocks in submarine calderas; (3) deposits associated with basaltic volcanic rocks. However, some deposits are associated with other volcanic settings. For example, Cas (1992) cites examples of Australian VMS deposits that are found in successions dominated by felsic "mass-flow deposits of resedimented pyroclastic debris" (see also McPhie and Allen 1992). Doyle and Allen (2003) give examples of other types of volcaniclastic deposits as well. Nevertheless, the three categories or groups presented here cover a good proportion of cases.

For this review, it was easier to find detailed and convincing volcanological studies of group 1 deposits than of group 2 deposits. One reason may be that the facies architecture of felsic domes and lavas is well known, relatively simple, and distinctive (e.g. McPhie et al. 1993). A felsic dome is limited in size and the spatial association with a VMS deposit should therefore be clear on local geological maps and cross-sections. Providing primary textures and structures are sufficiently preserved, a VMS deposit that is associated with a felsic dome or lava should be recognizable without much debate.

In contrast, demonstrating a caldera association in ancient successions can be difficult. First there is a scale challenge: silicic calderas tend to be large, so a regional study is necessary to identify one. Good exposure or extensive drilling coverage are therefore essential, but are not always available. Structural complexities can hamper the recognition of potential calderas in ancient successions. Several authors have emphasized great thicknesses (100s of $\mathrm{m}$ to several $\mathrm{km}$ ) of ignimbrite in the caldera, but distinguishing submarine pyroclastic flow deposits from other types of subaqueous pumiceous deposits is not straightforward and has led to much debate in the literature. One reason is that welded submarine pyroclastic rocks are very rare (Cas 1992; White 2000), so there are few obvious diagnostic criteria to distinguish primary from resedimented deposits. Glassy pumiceous deposits are especially prone to modification by diagenesis, hydrothermal alteration, tectonic deformation, and metamorphism (e.g., Gifkins et al. 2005). Also, a wide range of other volcaniclastic and even coherent volcanic rocks can acquire false pyroclastic textures (Allen 1988), leading to misidentification. Finally, there is no consensus regarding what a submarine caldera should look like, i.e. no accepted facies model showing the distribution of rock types.

Consequently, while there are certainly good examples of VMS or SMS deposits associated with calderas, such as the two reviewed above, other reported calderas in Australia and Japan (e.g., Ohmoto and Takahashi 1983) have been disproved or doubted in later studies (see Cas 1992; Allen and Weihed 2002). Yet following the discovery of the Sunrise SMS deposit in the late 1990s, the caldera model regained strength and classic VMS districts were reinterpreted as calderas or caldera complexes. For example, Stix et al. (2003) cite the Horne VMS deposit (Noranda district) as an example of a deposit located in a caldera margin environment, following the ideas of Gibson and Watkinson (1990) and Kerr and Gibson (1993). However, McNicoll et al. (2014) show through high-precision U-Pb geochronology that the $\sim 54 \mathrm{Mt}$ Horne deposit (plus $\sim 170 \mathrm{Mt}$ of subeconomic sulphide in Zone 5; MercierLangevin et al. 2011) and the neighbouring $\sim 14 \mathrm{Mt}$ Quemont deposit lie in rocks that are about 4 m.y. older 
than those hosting the "central camp" VMS deposits (such as Millenbach and Amulet) in the inferred centre of the Noranda cauldron, farther north. Therefore, Horne and Quemont do not seem to be related to a caldera margin setting. Taking it a step further, Mueller et al. (2009) proposed that the Bouchard-Hébert, Horne, and Quemont VMS deposits were associated with nested calderas in the Blake River Group of the Abitibi greenstone belt and that the calderas were comparable to modern "submarine arc calderas such as Myojin Knoll”. However, Mueller et al. (2009) also proposed that these Archean examples were "controlled predominantly by effusive-dominated caldera subsidence rather than explosive magma evacuation (e.g., Myojin Knoll caldera)" so it is not clear what they really meant. Without thick piles of pumiceous felsic pyroclastic deposits - which ought to be at least partly preserved in a subaqueous environment arguing for a large submarine caldera (e.g., Pearson and Daigneault 2009; Mueller et al. 2012) is difficult (see also Ross et al. 2011a, 2011b for more discussion on the Blake River Group). Recall that in subaerial settings, calderas produced by magma withdrawal or lava effusions are summit calderas many times smaller than the shield volcanoes or stratovolcanoes on which they occur. In summary, demonstrating the association between submarine calderas and VMS deposits in ancient successions is difficult, which may be why there are only a few truly convincing examples; alternatively, this association may be rarer than that between VMS deposits and felsic lava domes and flows.

Finally, we stress again that mafic volcanic rocks and sedimentary rocks can also be excellent hosts for VMS deposits (e.g., 300 Mt at Windy Craggy).

\section{ACKNOWLEDGEMENTS}

Most of the material presented here was initially compiled for a short course given by the first author at Québec Mines 2013 at the invitation of Patrice Roy. We then prepared this review for Geoscience Canada at the invitation of Jaroslav Dostal. We thank Rodney Allen, Claude Dion, Benoît Dubé, Réal Daigneault, Alan Galley, Harold Gibson, Jean Goutier, Michel Houlé, François Leclerc, Sylvain Lépine, Mario Masson, the late Wulf Mueller, Pierre Pilote, Gérald Riverin, Gilles Roy, Phil Thurston and our students for discussions about VMS districts and Abitibi geology. Our work in the Abitibi is funded by NSERC, the Geological Survey of Canada, Ministère des Ressources naturelles du Québec, and several exploration and mining companies.

\section{REFERENCES}

Allen, R.L., 1988, False pyroclastic textures in altered silicic lavas, with implications for volcanic-associated mineralization: Economic Geology, v. 83, p. 14241446.

Allen, R.L., 1992, Reconstruction of the tectonic, volcanic, and sedimentary setting of strongly deformed $\mathrm{Zn}$ $\mathrm{Cu}$ massive sulfide deposits at Benambra, Victoria: Economic Geology, v. 87, p. 825-854.

Allen, R.L., and Weihed, P., 2002, Global comparisons of volcanic-associated massive sulfide districts, in Blundell, D.J., Neubauer, F., and von Quadt, A., eds, The timing and location of major ore deposits in an evolving orogen: Geological Society (London), Special Publication 204, p. 13-37.

Allen, R., Weihed, P., and Svenson, S.-A., 1996a, Setting of $\mathrm{Zn}-\mathrm{Cu}-\mathrm{Au}-\mathrm{Ag}$ massive sulfide deposits in the evolution and facies architecture of a $1.9 \mathrm{Ga}$ marine volcanic arc, Skellefte District, Sweden: Economic Geology, v. 91, p. 1022-1053.

Allen, R.L., Lundstrom, I., Ripa, M., and Christofferson, H., 1996b, Facies analysis of a $1.9 \mathrm{Ga}$, continental margin, back-arc, felsic caldera province with diverse $\mathrm{Zn}-\mathrm{Pb}-\mathrm{Ag}-(\mathrm{Cu}-\mathrm{Au})$ sulfide and $\mathrm{Fe}$ oxide deposits, Bergslagen region, Sweden: Economic Geology, v. 91, p. 979-1008.

Baker, E.T., Walker, S.L., Embley, R.W., and De ronde, C.E.J., 2012, High-resolution hydrothermal mapping of Brothers caldera, Kermadec arc: Economic Geology, v. 107, p. 1583-1593.

Barrie, C.T., and Hannington, M.D., 1999, Classification of volcanic-associated massive sulfide deposits based on host rock composition, in Barrie, C.T., and Hannington, M.D., eds, Volcanic-associated massive sulfide deposits: processes and examples in modern and ancient settings: Society of Economic Geologists, Reviews in Economic Geology 8, p. 111.

Binns, R.A., and Scott, S.D., 1993, Actively forming polymetallic sulfide deposits associated with felsic volcanic rocks in the eastern Manus back-arc basin, Papua New Guinea: Economic Geology, v. 88, p. 2226-2236.

Bleeker, W., 1999, Structure, stratigraphy, and primary setting of the Kidd Creek volcanogenic massive sulfide deposit: a semiquantitative reconstruction, in Hannington, M.D., and Barrie, C.T., eds, The giant Kidd Creek volcanogenic massive sulfide deposit, western Abitibi Subprovince, Canada: Society of Economic Geologists, Monograph 10, p. 71-121.

Busby, C.J., Kessel., L., Schulz, K.J., Foose, M.P., and Slack, J.F., 2003, Volcanic setting of the Ordovician Bald Mountain massive sulfide deposit, northern Maine, in Goodfellow, W.D., McCutcheon, S.R., and Peter, J.M., eds, Massive sulfide deposits of the Bathurst mining camp, New Brunswick, and northern Maine: Society of Economic Geologists, Economic Geology Monograph 11, p. 219-244.

Cas, R.A.F., 1992, Submarine volcanism: eruption styles, products, and relevance to understanding the host- 
rock successions to volcanic-hosted massive sulfide deposits: Economic Geology, v. 87, p. 511-541.

Cole, J.W., Milner, D.M., and Spinks, K.D., 2005, Calderas and caldera structures: a review: Earth-Science Reviews, v. 69, p. 1-26.

Debreil., J.-A., 2014, Évolution volcanologique et chimicostratigraphique du district minier de Matagami, Sous-province de l'Abitibi, Québec: PhD thesis, Institut national de la recherche scientifique, Centre Eau Terre Environnement, Quebec City.

de Ronde, C.E.J., Hannington, M.D., Stoffers, P., Wright, I.C., Ditchburn, R.G., Reyes, A.G., Baker, E.T., Massoth, G.J., Lupton, J.E.,Walker, S.L., Greene, R.R., Soong, C.W.R., Ishibashi, J., Lebon, G.T., Bray, C.J., Resing, J.A., 2005, Evolution of a submarine magmatic-hydrothermal system: Brothers volcano, southern Kermadec arc, New Zealand: Economic Geology, v. 100, p. 1097-1133.

Doyle, M.G., and Allen, R.L., 2003, Subsea-floor replacement in volcanic-hosted massive sulfide deposits: Ore Geology Reviews, v. 23, p. 183-222.

Fiske, R.S., Naka, J., Iizasa, K., Yuasa, M., and Klaus, A., 2001, Submarine silicic caldera at the front of the Izu-Bonin arc, Japan: voluminous seafloor eruptions of rhyolite pumice: Geological Society of America Bulletin, v. 113, p. 813-824.

Franklin, J.M., Gibson, H.L., Jonasson, I.R., and Galley, A.G., 2005, Volcanogenic massive sulfide deposits, in Hedenquist, J.W., Thompson, J.F.H., Goldfarb, R.J., and Richards, J.P., eds, Economic Geology One Hundredth Anniversary Volume: Society of Economic Geologists, p. 523-560.

Galley, A.G., Hannington, M.D., and Jonasson, I.R., 2007, Volcanogenic massive sulphide deposits, in Goodfellow, W.D., ed., Mineral deposits of Canada: Geological Association of Canada, Mineral Deposits Division, Special Publication No. 5, p. 141-161.

Gibson, H.L., and Watkinson, D.H., 1990, Volcanogenic massive sulphide deposits of the Noranda Cauldron and shield volcano, Quebec, in Rive, M., Verpaelst, P., Gagnon, Y., Lulin, J.-M., Riverin, G., and Simard, A., eds, The northwestern Quebec polymetallic belt: a summary of 60 years of mining exploration: CIM Special Volume 43, p. 119-132.

Gibson, H., and Galley, A., 2007, Volcanogenic massive sulphide deposits of the Archean Noranda district, Quebec, in Goodfellow, W.D., ed, Mineral deposits of Canada: a synthesis of major deposits types, district metallogeny, the evolution of geological provinces, and exploration methods: Geological Association of Canada, Mineral Deposits Division, Special Publication 5, p. 533-552.

Gibson, H.L., Watkinson, D.H., Watkins, J.J., Labrie, M., and Doiron, G., 1993, Volcanological reconstruction of the Corbet breccia pile, and $\mathrm{Cu}-\mathrm{Zn}$ massive sulfide deposit, Noranda, Quebec: Exploration and Mining Geology, v. 2, p. 1-16.

Gibson, H.L., Morton, R.L., and Hudak, G.J., 1999, Submarine volcanic processes, deposits, and environments favorable for the location of volcanicassociated massive sulfide deposits, in Barrie, C.T., and Hannington, M.D., eds, Volcanic-associated massive sulfide deposits: processes and examples in modern and ancient settings: Society of Economic Geologists, Reviews in Economic Geology 8, p. 1351.

Gifkins, C., Herrmann, W., Large, R., 2005, Altered volcanic rocks; a guide to description and interpretation, Centre for Ore Deposit Research, University of Tasmania, Australia, $275 \mathrm{p}$.

Goutier, J., McNicoll, V., Mercier-Langevin, P., Dion, C., Ross, P.-S., 2011, Geologic evolution of the world's most prolific Archean VMS-bearing sequence: the Blake River Group, Abitibi greenstone belt, Canada $\square$ abstract $\square$. GAC-MAC 2011, Ottawa, Ontario.

Hannington, M.D., Galley, A.G., Herzig, P.M., and Petersen, S., 1998, Comparison of the TAG mound and stockwork complex with Cyprus-type massive sulphide deposits, in Proceedings of the Ocean Drilling Program, Scientific Results Volume 158: p. 389-415.

Hannington, M.D., Bleeker, W., and Kjarsgaard, I., 1999, Sulfide mineralogy, geochemistry and ore genesis of the Kidd Creek deposit: Part 1. North, Central and South orebodies, in Hannington, M.D., and Barrie, C.T., eds, The giant Kidd Creek volcanogenic massive sulfide deposit, western Abitibi Subprovince, Canada: Economic Geology Monograph 10, p. 163-224.

Hannington, M.D., de Ronde, C.E.J., and Petersen, S., 2005, Sea-floor tectonics and submarine hydrothermal systems, in Hedenquist, J.W., Thompson, J.F.H., Goldfarb, R.J., and Richards, J.P., eds, Economic Geology One Hundredth Anniversary Volume: Society of Economic Geologists, p. 111-141.

Horikoshi, E., 1969, Volcanic activity related to the formation of the Kuroko-type deposits in the Kosaka district, Japan: Mineralium Deposita, v. 4, p. 321-345.

Hudak, G.J., Morton, R.L., Franklin, J.M., and Peterson, D.M., 2003, Morphology, distribution, and estimated eruption volumes for intracaldera tuffs associated with volcanic-hosted massive sulfide deposits in the Archean Sturgeon Lake Caldera Complex, northwestern Ontario, in White, J.D.L., Smellie, J.L., and Clague, D.A., eds, Explosive Subaqueous Volcanism: American Geophysical Union, Geophysical Monograph 140, p. 345-360.

Iizasa, K., Fiske, R.S., Ishizuka, O., Yuasa, M., Hashimoto, J., Ishibashi, J., Naka, J., Horii, Y., Fujiwara, Y., Imai, A., and Koyama, S., 1999, A Kuroko-type polymetallic sulfide deposit in a submarine silicic caldera: Science, v. 283, p. 975-977.

Kerr, D.J., and Gibson, H.L., 1993, A comparison of the Horne volcanogenic massive sulfide deposit and intracauldron deposits of the Mine Sequence, Noranda, Quebec: Economic Geology, v. 88, p. 1419-1442.

Knuckey, M.J., Comba, C.D.A., and Riverin, G., 1982, Structure, metal zoning and alteration at the Millenbach deposit, Noranda, Quebec, in Hutchinson, R.W., Spence, C.D., and Franklin, 
J.M., eds, Precambrian sulphide deposits: Geological Association of Canada, Special Paper 25 , p. $255-295$.

Kuroda, H., 1983, Geologic characteristics and formation environments of the Furutobe and Matsuki Kuroko deposits, Akita prefecture, northeast Japan, in Ohmoto, H., and Skinner, B.J., eds, The Kuroko and related volcanogenic massive sulfide deposits: Society of Economic Geologists, Economic Geology Monograph 5, p. 149-166.

Lipman, P.W., 1997, Subsidence of ash-flow calderas: relation to caldera size and magma-chamber geometry: Bulletin of Volcanology, v. 59, p. 198218.

Lipton, I., 2012, Mineral resource estimate, Solwara project, Bismark Sea, PNG: Golder Associated Pty Ltd. for Nautilus Minerals Inc., 217 p., downloaded from www.nautilusminerals.com on Jan. 9, 2014.

McNicoll, V., Goutier, J., Dubé, B., Mercier-Langevin, P., Ross, P.-S., Dion, C., Monecke, T., Legault, M., Percival, J., and Gibson, H., 2014, U-Pb geochronology of the Blake River Group, Abitibi Greenstone Belt, Quebec, and implications for base metal exploration: Economic Geology, v. 109, p. 27-59.

McPhie, J., and Allen, R.L., 1992, Facies architecture of mineralized submarine volcanic sequences: Cambrian Mount Read Volcanics, western Tasmania: Economic Geology, v. 87, p. 587-596.

McPhie, J., Doyle, M., Allen, R., 1993, Volcanic textures: a guide to the interpretation of textures in volcanic rocks: University of Tasmania, Hobart, Australia, $196 \mathrm{p}$.

Mercier-Langevin, P., Goutier, J., Ross, P.-S., McNicoll, V., Monecke, T., Dion, C., Dubé, B., Thurston, P., Bécu, V., Gibson, H., Hannington, M., and Galley, A., 2011, The Blake River Group of the Abitibi greenstone belt and its unique VMS and gold-rich VMS endowment: Geological Survey of Canada Open File 6869, 61 p. doi:10.495/288757

Mercier-Langevin, P., McNicoll, V., Allen, R.L., Blight, J.H.S., and Dubé, B., 2013, The Boliden gold-rich volcanogenic massive sulfide deposit, Skellefte district, Sweden: New U-Pb age constraints and implications at deposit and district scale: Mineralium Deposita, v. 48, p. 485-504.

Mercier-Langevin, P., Gibson, H.L., Hannington, M.D., Goutier, J., Monecke, T., Dubé, B., and Houlé, M., 2014, A Special Issue on Archean Magmatism, Volcanism, and Ore Deposits: Part 2. Volcanogenic Massive Sulfide Deposits Preface: Economic Geology, v. 109, p. 1-9.

Morton, R.L., and Franklin, J.M., 1987, Two-fold classification of Archean volcanic-associated massive sulfide deposits: Economic Geology, v. 82, p. 1057-1063.

Mueller, W.U., Stix, J., Corcoran, P.L., and Daigneault, R., 2009, Subaqueous calderas in the Archean Abitibi greenstone belt: An overview and new ideas: Ore Geology Reviews, v. 35, p. 4-46.

Mueller, W.U., Friedman, R., Daigneault, R., Moore, L., and Mortensen, J., 2012, Timing and characteristics of the Archean subaqueous Blake River Megacaldera Complex, Abitibi greenstone belt, Canada: Precambrian Research, v. 214-215, p. 1-27.

Ohmoto, H., 1996, Formation of volcanogenic massive sulfide deposits: the Kuroko perspective: Ore Geology Reviews, v. 10, p. 135-177.

Ohmoto, H., and Takahashi, T., 1983, Submarine calderas and Kuroko genesis, in Ohmoto, H., and Skinner, B.J., eds, The Kuroko and related volcanogenic massive sulfide deposits: Society of Economic Geologists, Economic Geology Monograph 5, p. 39-49.

Paulick, H., Vanko, D.A., and Yeats, C.J., 2004, Drill corebased facies reconstruction of a deep-marine felsic volcano hosting an active hydrothermal system (Pual Ridge, Papau New Guinea, ODP Leg 193): Journal of Volcanology and Geothermal Research, v. 130 , p. $31-50$.

Pearson, V., and Daigneault, R., 2009, An Archean megacaldera complex: the Blake River Group, Abitibi greenstone belt: Precambrian Research, v. 168 , p. 66-82.

Peter, J.M., and Scott, S.D., 1999, Windy Craggy, northwestern British Columbia: the world's largest Besshi-type deposit, in Barrie, C.T., and Hannington, M.D., eds, Volcanic-associated massive sulfide deposits: processes and examples in modern and ancient settings: Society of Economic Geologists, Reviews in Economic Geology 8, p. 261-295.

Relvas, J.M.R.S., Barriga, F.J.A.S., Ferreira, A., Noiva, P.C., Pacheco, N., and Barriga, G., 2006, Hydrothermal alteration and mineralization in the Neves-Corvo volcanic-hosted massive sulfide deposit, Portugal. I. geology, mineralogy, and geochemistry: Economic Geology, v. 101, p. 753-790.

Rogers, R., Ross, P.-S., Goutier, J., and Mercier-Langevin, P., 2014, Using physical volcanology, chemical stratigraphy, and pyrite geochemistry for volcanogenic massive sulfide exploration: an example from the Blake River Group, Abitibi Greenstone Belt: Economic Geology, v. 109, p. 6188.

Rosa, C.J.P., McPhie, J., Relvas, J.M.R.S., Pereira, Z., Oliveira, T., and Pacheco, N., 2008, Facies analyses and volcanic setting of the giant Neves Corvo massive sulfide deposit, Iberian Pyrite Belt, Portugal: Mineralium Deposita, v. 43, p. 449-466.

Rosa, C.J.P., McPhie, J., and Relvas, J.M.R.S., 2010, Type of volcanoes hosting the massive sulfide deposits of the Iberian Pyrite Belt: Journal of Volcanology and Geothermal Research, v. 194, p. 107-126.

Ross, P.-S., Goutier, J., Mercier-Langevin, P., and Dubé, B., 2011a, Basaltic to andesitic volcaniclastic rocks in the Blake River Group, Abitibi Greenstone Belt: 1. Mode of emplacement in three areas: Canadian Journal of Earth Sciences, v. 48, p. 728-756.

Ross, P.-S., McNicoll, V., Goutier, J., Mercier-Langevin, P., and Dubé, B., 2011b, Basaltic to andesitic volcaniclastic rocks in the Blake River Group, Abitibi Greenstone Belt: 2. Origin, geochemistry, 
and geochronology: Canadian Journal of Earth Sciences, v. 48, p. 757-777.

Scott, S.D., and Binns, R.A., 1995, Hydrothermal processes and contrasting styles of mineralization in the western Woodlark and eastern Manus basins of the western Pacific: Geological Society (London), Special Publication 87, p. 191-205.

Shanks, W.C.P., and Thurston, R., 2012, Volcanogenic massive sulfide occurrence model: U.S. Geological Survey, Scientific Investigations Report 2010-5070$\mathrm{C}, 345 \mathrm{p}$.

Slack, J.F., Foose, M.P., Flohr, M.J.K., Scully, M.V., and Belkin, H.E., 2003, Exhalative and subsea-floor replacement processes in the formation of the Bald Mountain massive sulfide deposit, northern Maine, in Goodfellow, W.D., McCutcheon, S.R., and Peter, J.M., eds, Massive sulfide deposits of the Bathurst mining camp, New Brunswick, and northern Maine: Society of Economic Geologists, Economic Geology Monograph 11, p. 513-547.

Smith, R.L., and Bailey, R.A., 1968, Resurgent caldrons, in Coats, R.R., Hay, R.L., and Anderson, C.A., eds, Studies in volcanology: Geological Society of America, Memoir 116, p. 613-662.

Soriano, C., and Marti, J., 1999, Facies analysis of volcanosedimentary successions hosting massive sulfide deposits in the Iberian pyrite belt, Spain: Economic Geology, v. 94, p. 867-882.

Stix, J., Kennedy, B., Hannington, M., Gibson, H., Fiske, R., Mueller, W., and Franklin, J., 2003, Calderaforming processes and the origin of submarine volcanogenetic massive sulfide deposits: Geology, v. 31, p. $375-378$

Tanimura, S., Date, J., Takahashi, T., and Ohmoto, H., 1983, Stratigraphy and structure of the Hokuroku district, in Ohmoto, H., and Skinner, B.J., eds, The Kuroko and related volcanogenic massive sulfide deposits: Society of Economic Geologists, Economic Geology Monograph 5, p. 24-39.

Tornos, F., 2006, Environment of formation and styles of volcanogenic massive sulfides: The Iberian Pyrite Belt: Ore Geology Reviews, v. 28, p. 259-307.

Walker, G.P.L., 1993, Basaltic-volcano systems, in Prichard, H.M., Alabaster, T., Harris, N.B.W., and Beary, C.R., eds, Magmatic Processes and Plate Tectonics: Geological Society Special Publication 76, p. 3-38.

White, J.D.L., 2000, Subaqueous eruption-fed density currents and their deposits: Precambrian Research, v. 101, p. $87-109$.

White, J.D.L., and Houghton, B.F., 2006, Primary volcaniclastic rocks: Geology, v. 34, p. 677-680.

Yamada, R., and Yoshida, T., 2011, Relationships between Kuroko volcanogenic massive sulfide (VMS) deposits, felsic volcanism, and island arc development in the northeast Honshu arc, Japan: Mineralium Deposita, v. 46, p. 431-448.

Yuasa, M., and Kano, K., 2003, Submarine silicic calderas on the northern Shichito-Iwojima Ridge, IzuOgasawara (Bonin) Arc, western Pacific, in White, J.D.L., Smellie, J.L., and Clague, D.A., eds, Explosive subaqueous volcanism: American Geophysical Union, Geophysical Monograph 140, p. 231-243.

Zierenberg, R.A., Shanks, W.C., Seyfried, W.E., Koski, R.A., and Strickler, M.D., 1988, Mineralization, alteration, and hydrothermal metamorphism of the ophiolite-hosted Turner-Albright sulfide deposit, southwestern Oregon: Journal of Geophysical Research, v. 93, p. 4657-4674.

\section{Figure captions}

Figure 1. Section (a) and facies model (b) showing dacitic lava flows/domes and distribution of massive sulphide deposits at Solwara-4 in the Manus Basin. The two sites drilled, Snowcap and Roman Ruins, are approximately 600 $\mathrm{m}$ apart. "mbsl" = metres below sea level. Reused from Paulick et al. (2004) with permission from Elsevier (licence 3303690703269).

Figure 2. Vertical cross-section at the Hanaoka mine, Hokuroku district, Japan, showing the association between lava domes and Kuroko deposits. Simplified from Yamada and Yoshida (2011).

Figure 3. Schematic diagrams of the Neves Corvo area showing: (a) emplacement of rhyolite lavas/domes on a mudstone substrate; (b) deposition of VMS ore bodies and more mudstone. Modified from Rosa et al. (2008).

Figure 4. Facies model for "subaqueous rhyolite cryptodome-tuff volcanoes" in the Skellefte district. Modified from Allen et al. (1996a).

Figure 5. Block diagram showing the initial development of the Kidd Creek VMS deposit. A rhyolite flow-dome complex is emplaced in a subsiding graben or half-graben. The structure is then filled by volcaniclastic debris from sources including the flow-dome complex. Hydrothermal fluids permeate this fragmental pile and VMS orebodies form below the seafloor. Figure modified from Bleeker (1999). Note the x2 vertical exaggeration. 
Figure 6. Reconstruction of the "Millenbach dome complex", which is a rhyolite ridge found above its feeding fissure, in the Noranda district. This ridge consists of a series of blocky domes/lava flows, upon which is a series of VMS ore lenses. Modified from Gibson and Galley (2007).

Figure 7. Sketch showing the development of a submarine caldera and associated VMS deposits: (a) influx of seawater into the magma chamber; (b) development of hydrothermal cells. Modified from Stix et al. (2003).

Figure 8. Geological map of the Myojin Knoll caldera showing the distribution of the syn-caldera pumice and the location of the Sunrise SMS deposit ("postcaldera polymetallic sulphide deposit"). Republished from Fiske et al. (2001) with permission of the Geological Society of America; permission conveyed through Copyright Clearance Center Inc, licence 3303720448684.

Figure 9. Schematic block diagrams showing the evolution of the Bald Mountain sequence: (a) eruption of footwall ignimbrite and collapse of the Bald Mountain sub-basin, then growth of the VMS deposit within the ignimbrite vent; (b) collapse of the Bull Hill sub-basin and eruption of the hanging wall ignimbrite, covering the VMS deposit.

Modified from Busby et al. (2003).

Figure 10. Schematic stratigraphic section through the Windy Craggy deposit. Modified from Peter and Scott (1999) and Franklin et al. (2005). 
$\mathbf{a}$

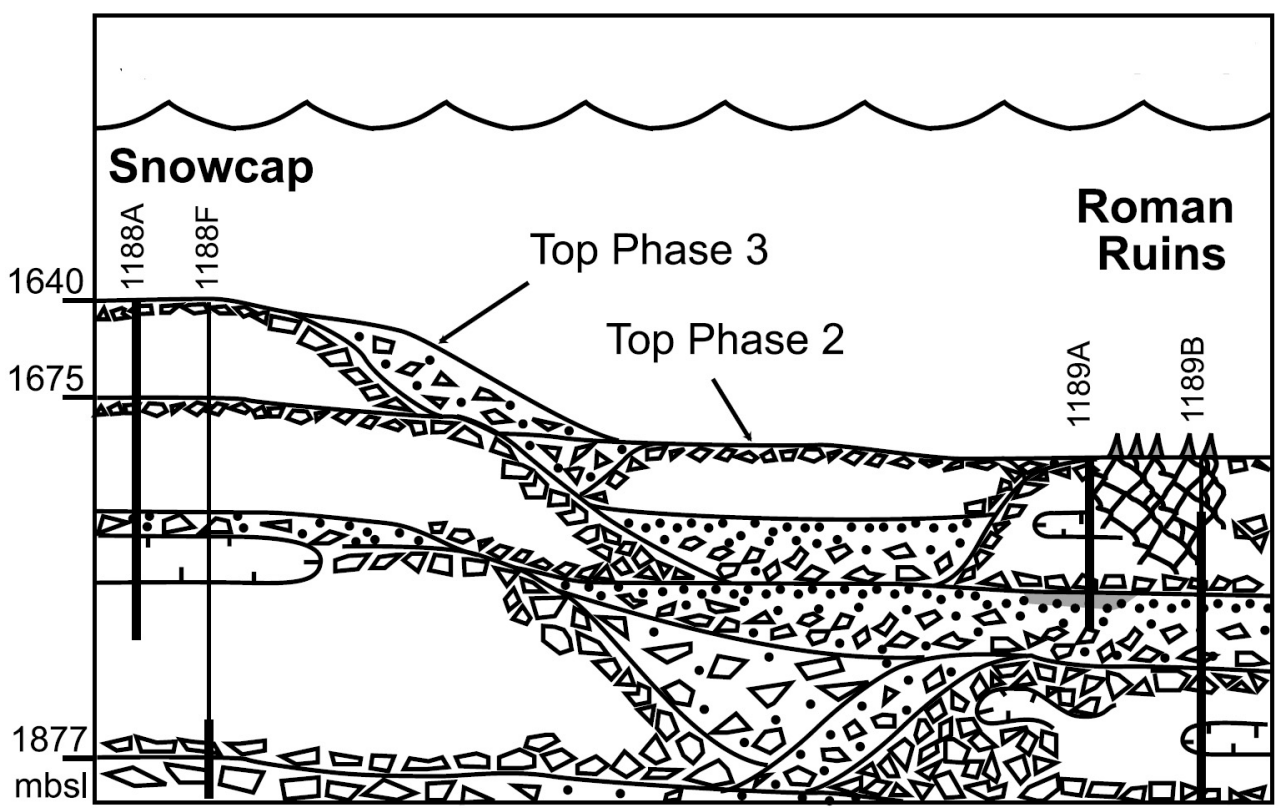

b

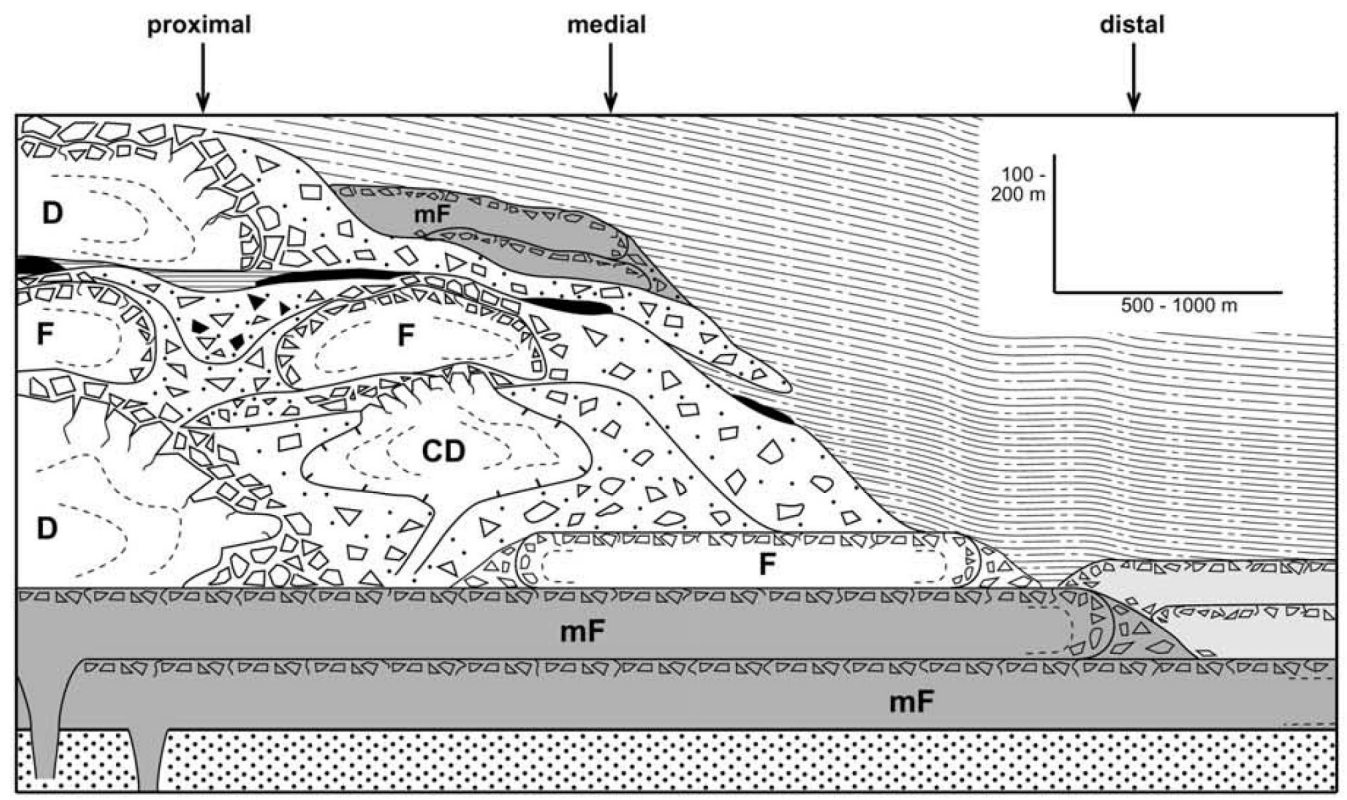

\section{volcanic facies}

felsic lava: CD: cryptodome D: dome; F: flow mafic lava flow: $\mathrm{mF}$

lava flows derived from adjacent volcanoes

$\square \Delta \nabla \nabla$

in-situ hyaloclastite/autobreccia

$\nabla \cdot \dot{\square} \dot{\square}$ resedimented

hyaloclastite/autobreccia

locally derived, polymictic breccia

TI intrusive contact sedimentary facies (background sedimentation)

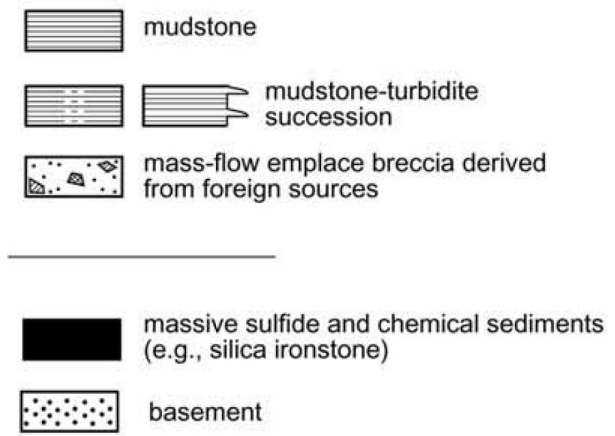

$\because \because \because$ basement 


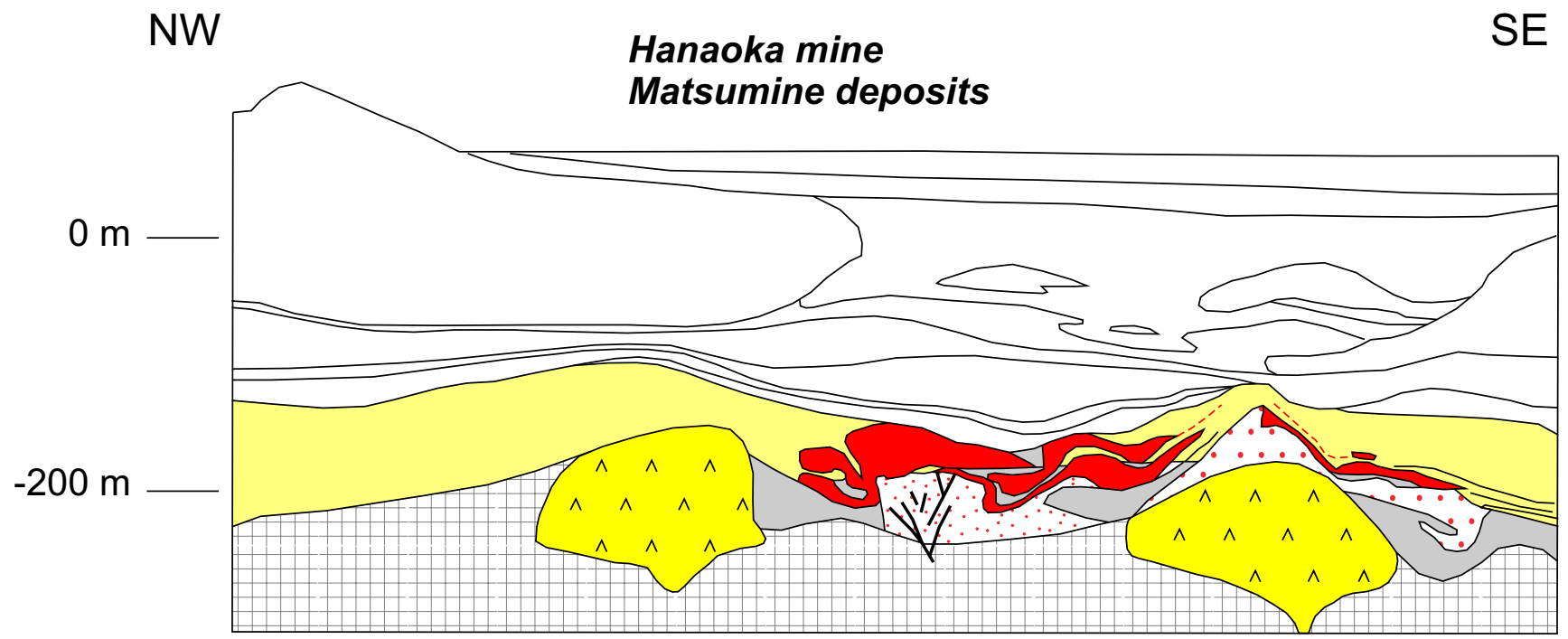

$500 \mathrm{~m}$

Post-Kuroko

Quaternary to Miocene

Pre- to syn-ore

Black ore, yellow ore, siliceous ore

Massive pyrite

$\because \cdots \quad$ Massive gypsum
Pre- to syn-ore (cont.)

Clay zone

$\wedge \quad$ Rhyolite domes and related felsic tuff breccias

\section{Pre-Kuroko}

Dacitic to rhyolitic lavas (Miocene) 

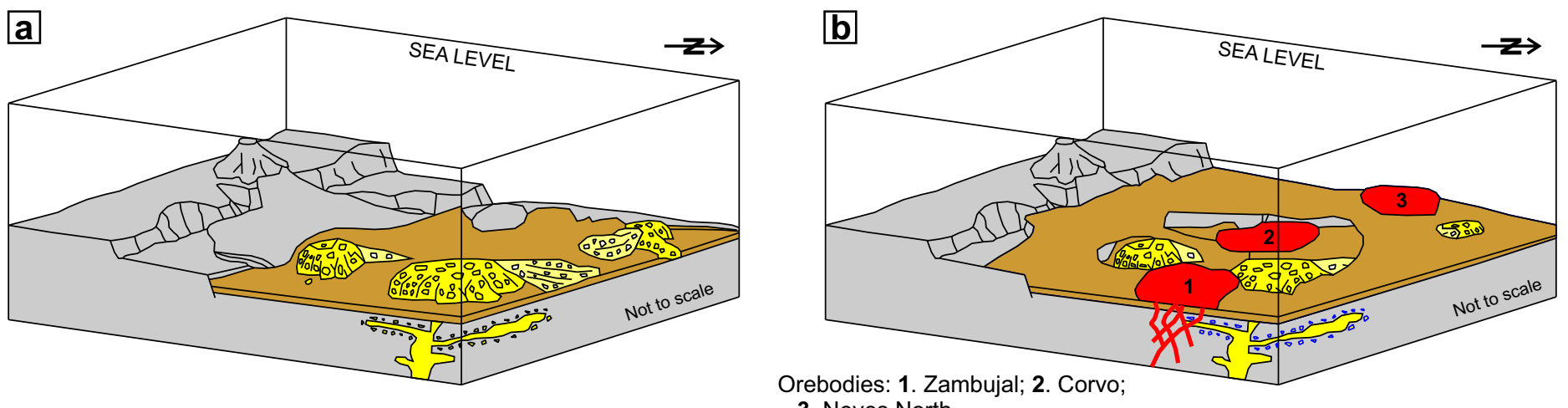

Mineralization

Massive sulphide and stockworks

\section{Sedimentary rocks}

Neves Formation (mudstone)
Rhyolite

Coherent

$\triangle$ Jigsaw-fit and clast-rotated monomictic bx

D Stratified monomictic breccia

\section{Older rocks}

Sedimentary to volcanic 


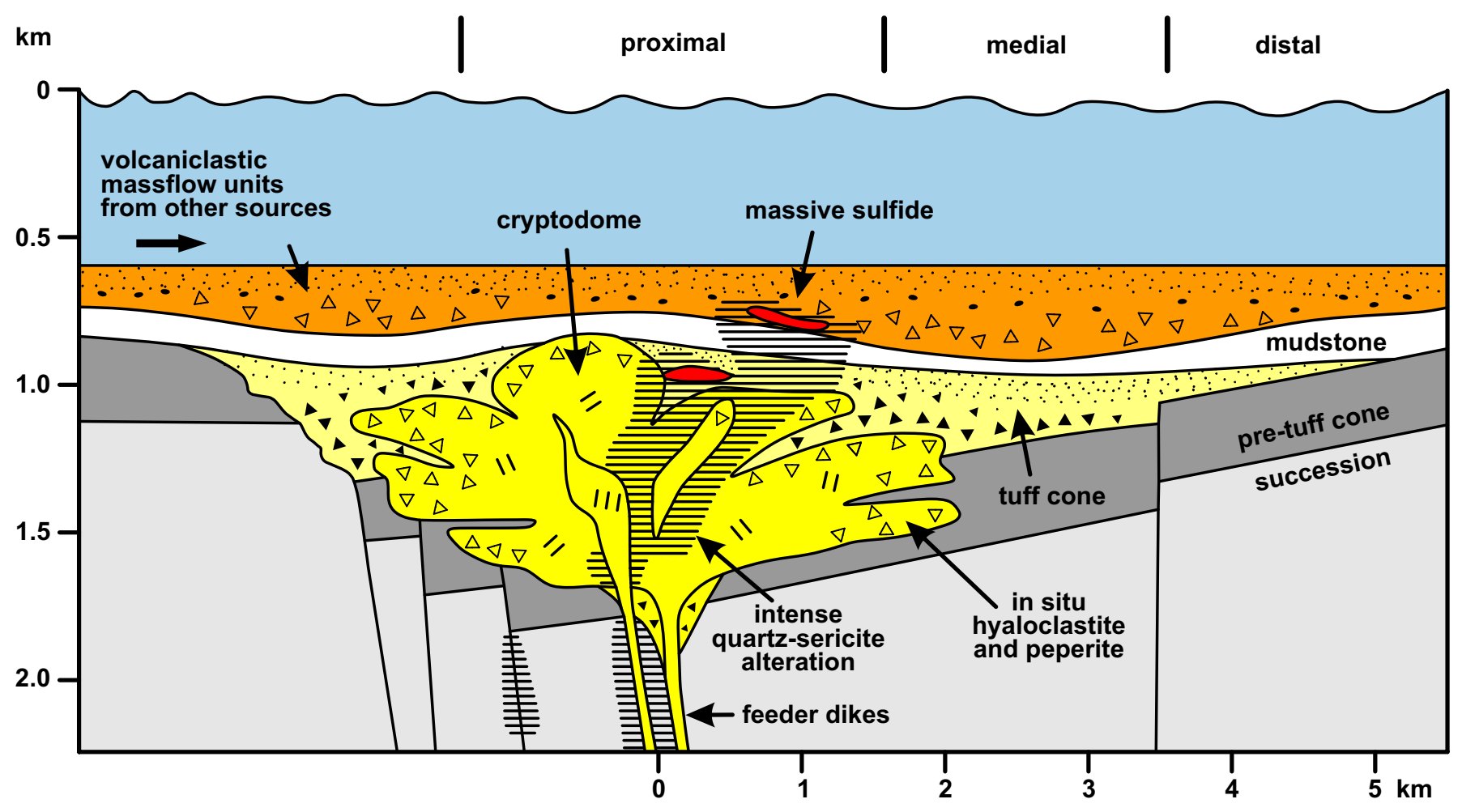




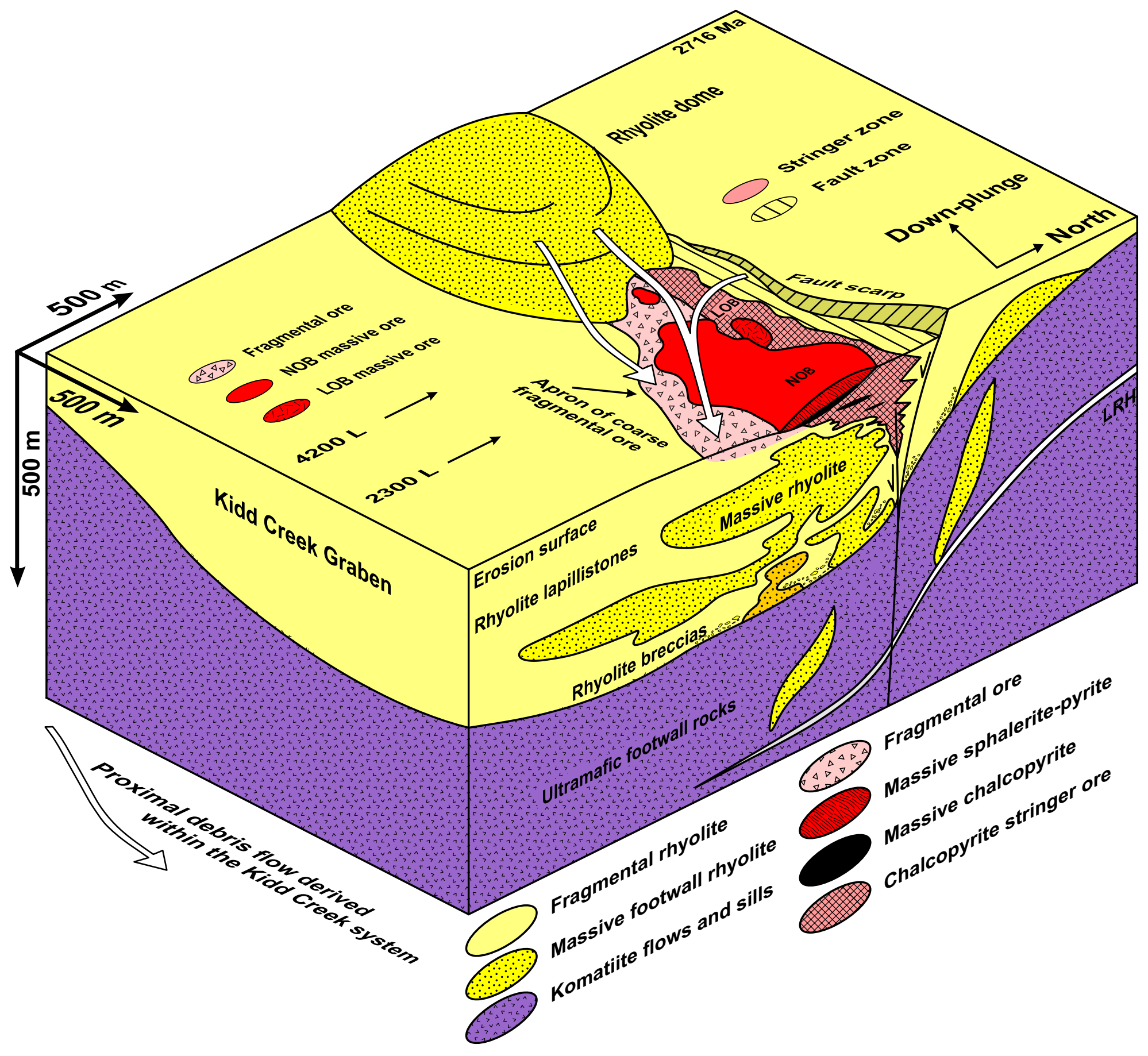




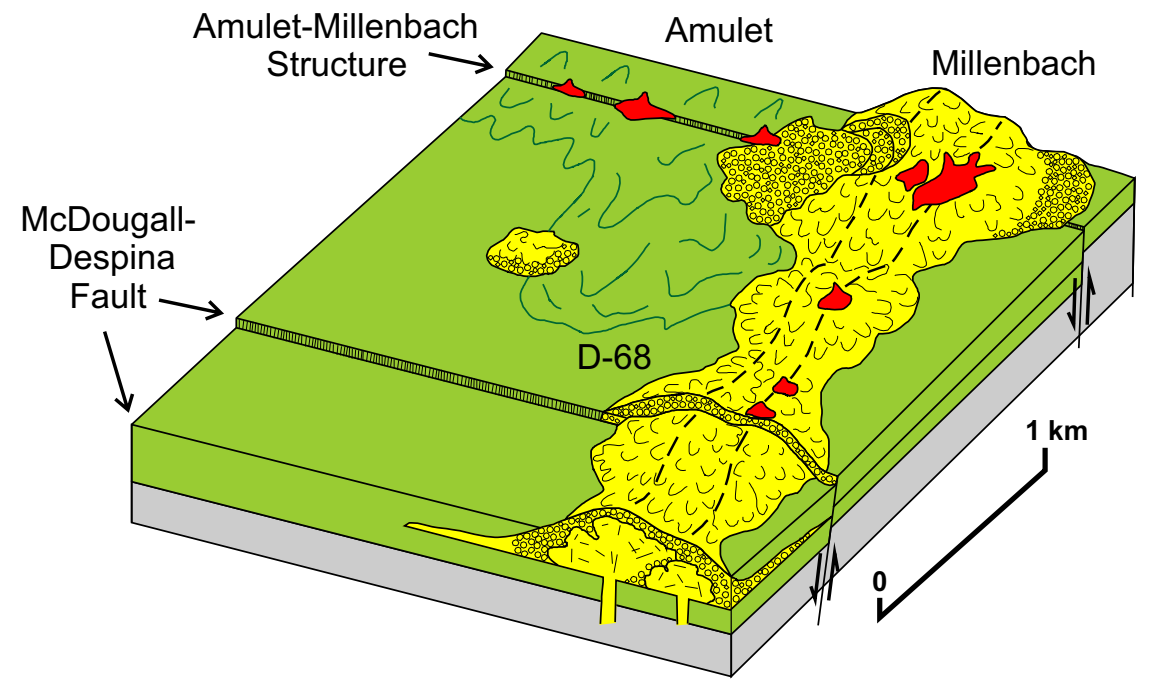

\section{Legend}

Millenbach Rhyolite Fm

Millenbach Andesite Fm

Older volcanic formation 
a

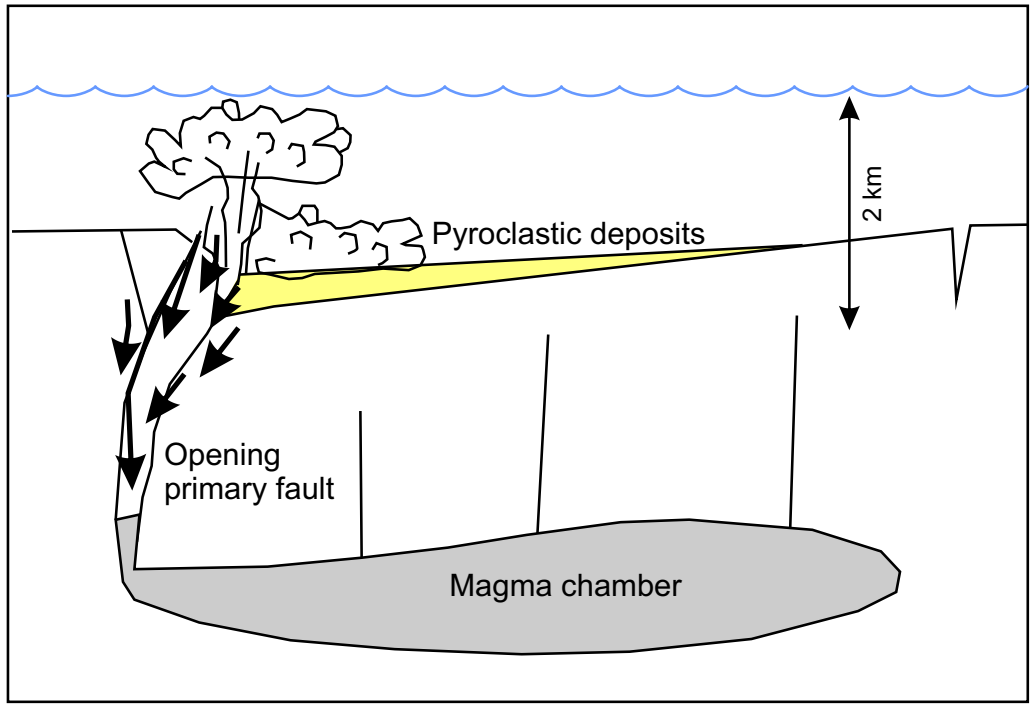

b

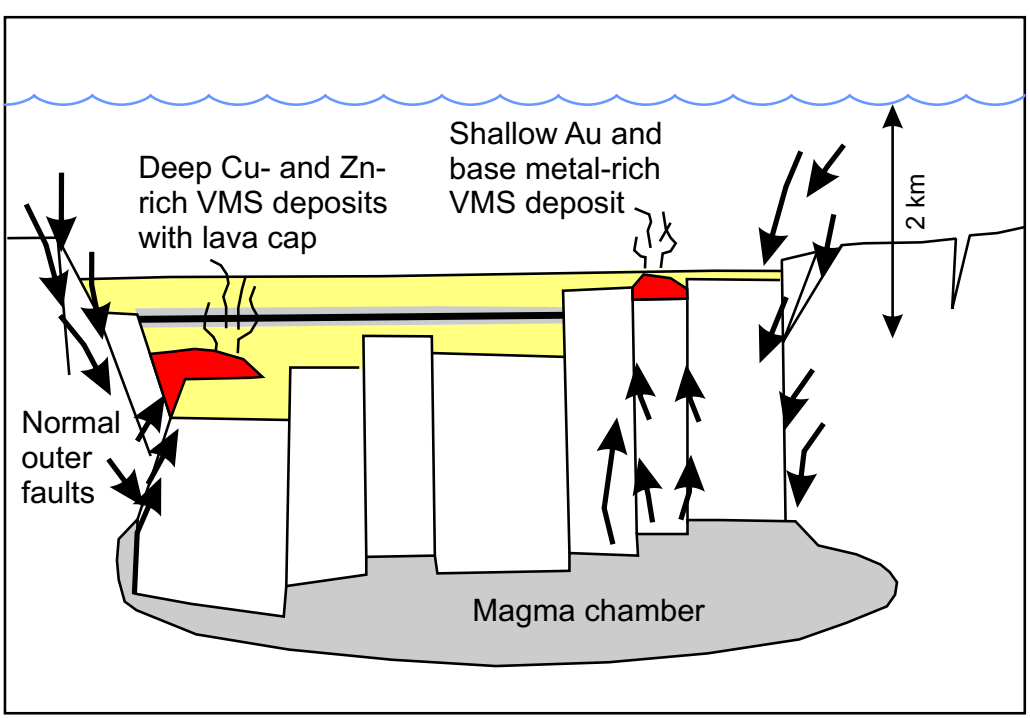




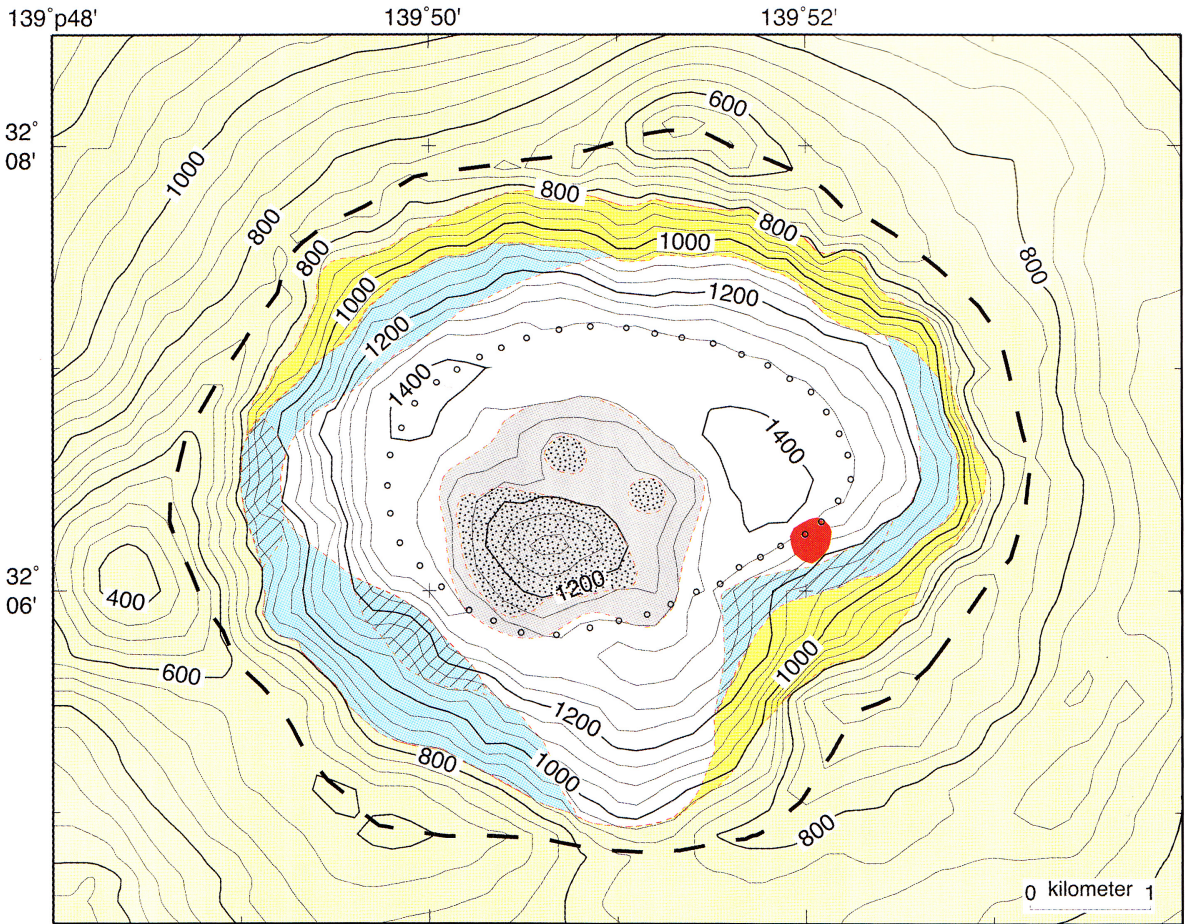

postcaldera polymetallic sulfide deposit

postcaldera dome, mantled by uplifted caldera-floor deposits; coarser pattern where exposed

talus and caldera fill

syncaldera pumice deposits precaldera pumice deposits

precaldera lava flows, shallow intrusion, and volcaniclastic deposits; hatched areas are massive rhyolite

- caldera rim 
a

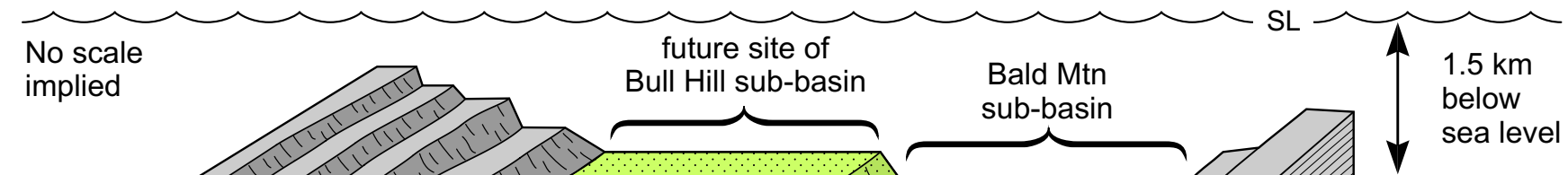

b

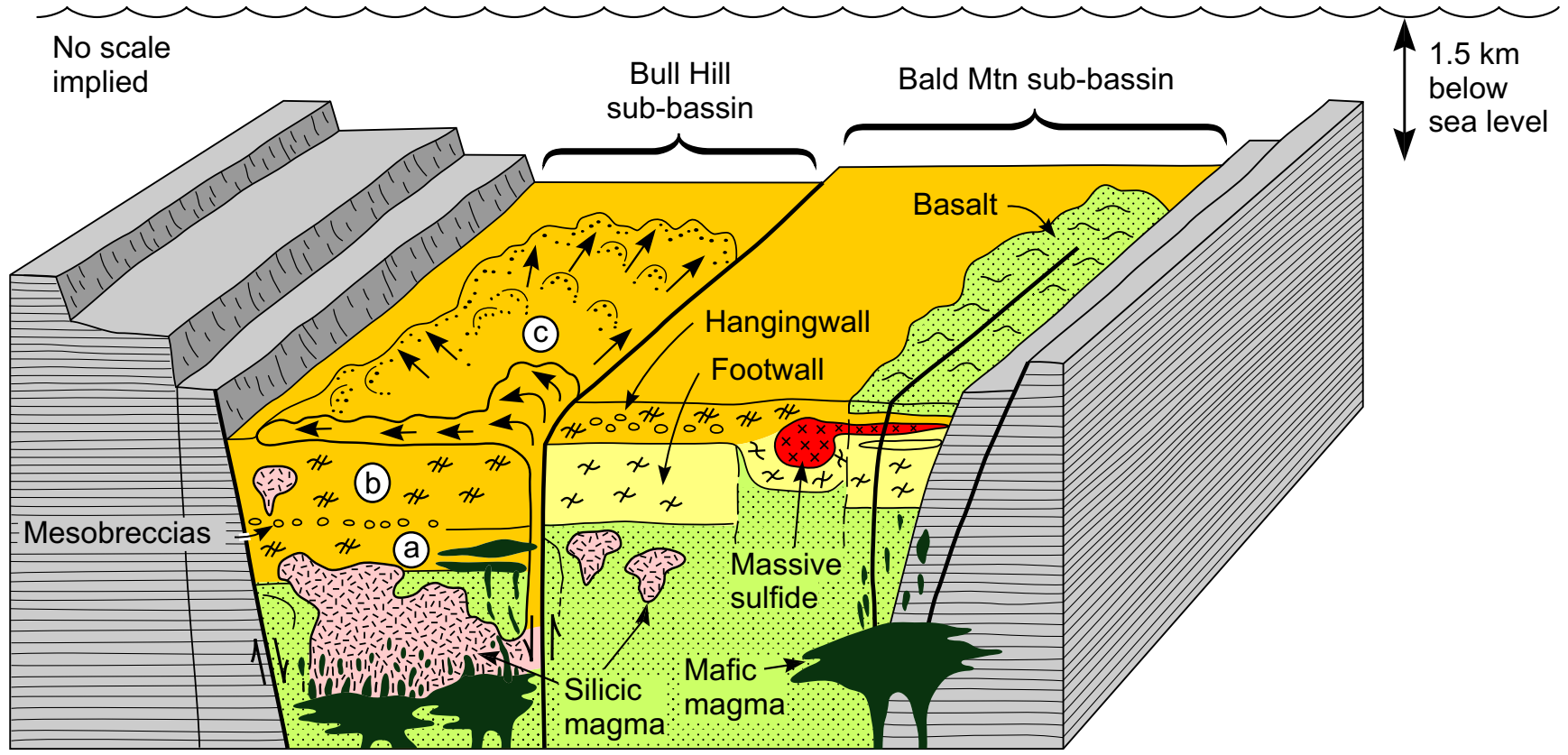

a Crystal-rich Ignimbrite interstratified with basalt lava flows and mesobreccia.

Deposited across both sub-basins and then downdropped in Bull Hill sub-basin,

to be overlain by:

(b) Crystal-poor hangingwall ignimbrite.

C Hangingwall ignimbrite vent not located but abundant peperitic intrusive equivalents indicate proximity to vent. 


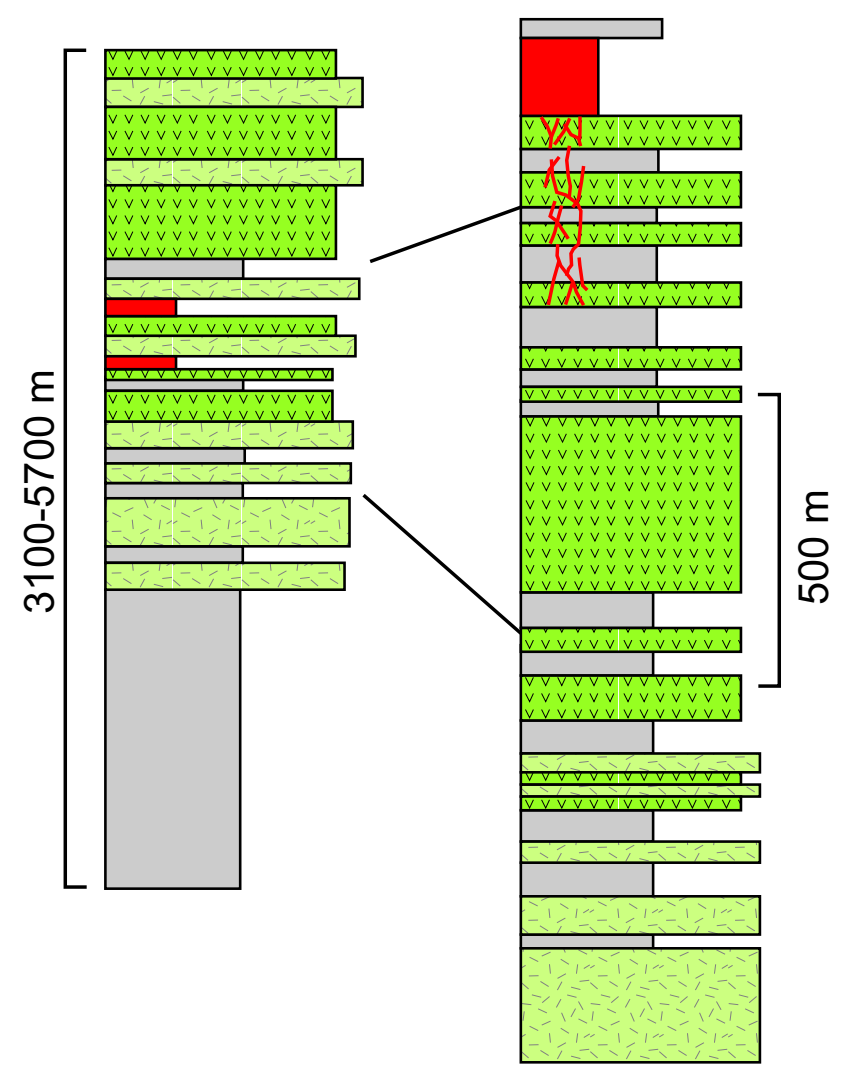

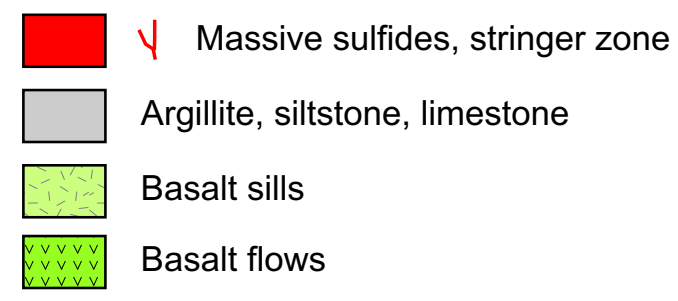

